\title{
高次近似のはり理論の定式化ならびに各種のはり理論の精度特性 FORMULATION OF A BEAM THEORY DUE TO HIGHER-ORDER APPROXIMATION AND ACCURACY OF TYPICAL BEAM THEORIES
}

\author{
平島 健 一**・根岸嘉 和** \\ By Ken-ichi HIRASHIMA and Yoshikazu NEGISHI
}

\begin{abstract}
In this paper, the most general higher-order equations of one-dimensional static and dynamic theories for generally anisotropic elastic beams are proposed by expanding the displacements of infinite Power series with respect to the transverse coordinate of the beam.

Several beam theories which were proposed previously, can be deduced by the particular cases with employment of the lower-order terms of our theory and with specialization of the constitutive equations.

On the other hand, we apply the previously proposed plate theories including the effect of transverse deformations to the beam analysis, and examine the special theoretical and numerical charachteristics of the various beam theories through the application to some static and dynamic problems.
\end{abstract}

\section{1. まえがき}

Bernoulli-Euler の平面保持の仮定に立脚した古典は り理論は, その簡潔さ, 取扱いの容易さのために解析が 非常に簡単になり，実用性を含めた工学の分野にきわめ て大きな貢献をしたが, 厳密には純曲げ以外の横荷重を 受けたはり断面は, そのはり高 $h$ とスパン $L$ の比 $h / L$ が堌大するにつれ，一般に非線形的にゆがんだ面となっ て古典理論の仮定から離反した結果となってゆく.これ は古典理論では, はりを実際より剛な構造として評価し ていることに相当し，曲げ効果に比してせん断効果の影 響が強くなる deep-beam の問題や短い周期幅で変化す る静荷重を受けるはりの問題, ならびに異方性の強いは り, サンドイッチはり（層状性はり）さらにははりの高 周波振動および短波長の波動の伝播の解析においては, 古典はり理論の適用が困難となる場合も少なくない.

この弱点を改善するためのはり理論の修正の試みは, Timoshenko が 1921 年に, はりのせん断変形理論 ${ }^{1}$ を提 案して以来活発に行われ, 各種の改良理論が多数の研究

* 正会員 工博 山梨大学助教授 工学部土木工学科 ( ₹400 早府市武田 4-3-11)

** 正会員 工修 福島工業高等専門学校講師 土木工学科 ( テ970 いわき市平上荒川字長尾 30)
者によって提案されて現在に至っている. Timoshenko は古典はり理論にせん断変形と回転慣性を考慮した，い わゆる Timoshenko はりの理論を提示したのであるが, これは横荷重を受けて変形したはりの断面は, 変形後の 中立軸に対し直角を保持せず，せん断変形分だけ傾いた 法線をもつ平面となるとする理論である.これによると 断面はあくまで平面のまま保持されており，したがって 高さ方向に一定のせん断変形を考慮したことになり，上 下表面の境界 (荷重) 条件が一般に満たされていない定 式化である。これに対する補正手段として Timoshenko は 1922 年の論文 ${ }^{2)}$ でせん断補正係数 $\varkappa^{2}$ を導入し, 変形 後の平面が, 実際の非線形な変形面の重みつき平均とな るように補正することによって, 非一様なせん断変形の 存在を間接的に考慮した。一方，たとえばはりの高さ方 向に 2 次放物線分布のせん断変形を仮定した理論の一つ として最近, Rehfield と Murthy ${ }^{3)}$ は古典理論における 忘力成分の表示をそれらの初期值として用いた逐次近似 的な定式化により, 変位成分と曲げ応力の修正を行い, せん断変形, はりの高さ方向の直応力, 直ひずみ, さら に鈶直荷重による軸方向伸縮を考慮したはり理論を提案 している. また，西野と椿 ${ }^{4)}$ はせん断変形を考慮したは りの逐次近似理論を提案しているが，これは断面形不変 の仮定を保持したままで法線保持の拘束をはすし，逐次 
せん断変形分布を高次化させていく理論であり，そこで は高さ方向の直応力および直ひずみならびにはりの軸方 向伸縮挙動は考慮されていない.

他方, 高次の断面の変形をその定式化の最初の段階で 具体的に考慮した理論として, Gupta と Pathak ${ }^{5}$ ははり の変位場を, はりの高さ方向の座標に関するべキ級数で 展開し, 軸方向変位 $u_{x}$ に奇数次項のみを, 高さ方向変 位 $u_{z}$ には偶数次項のみをそれぞれ採用した変位場を仮 定し，おのおの 1 次と 3 次の項および 0 次と 2 次の項を 取った高次はり理論を定式化している．しかしこの理論 は, その採用項の次数からわかるように, 曲げ挙動のみ に着目したものとなってる.

本論文においては, 微小変位の基本仮定を設定し一般 的な異方性体よりなるはりの静的ならびに動的な問題に 関して, 奥行き方向に対して平面問題としてのはりの変 位場を, はりの高さ方向の座標に関する無限項のベキ級 数で展開した変位仮定に基づく, 一般化高次はり理論を 定式化するとともに，従来提案されている代表的なはり 理論とここでの理論との関係を明らかにする．また応力 場の仮定に基づく代表的な平板のせん断変形理論をはり の問題に適用して定式化し，それらを2 次元弾性論に よって解かれるいくつかのはり問題に適用した例やそれ 以外に提案されているはり理論による解析を通して，各 理論間の関係を明らかにし，はり理論の系統的な整理, 位置づけを武みる。なおはりは等質で一定の高さである と仮定する.

\section{2. 一般化高次はり理論の定式化}

ここでは，一般的な異方性体よりなるはりに対し，奥 行き方向 $\left(x_{2}\right.$ 方向) に平面問題としての一般化高次は り理論の運動方程式と境界条件式を導き, 等方性はりの 場合について，その具体形を示す.なおここで対象と するはりおよび座標系を Fig. 1 に示すように設定する.

まず,はりの変位場を次のように仮定する.

$$
u_{j}\left(x_{1}, x_{3}, t\right)=\sum_{n=0}^{\infty} x_{3}^{n} \cdot u_{j}^{(n)}\left(x_{1}, t\right) \cdot
$$

式（1）の変位を，幾何学的関係式（ひずみ-変位関係） に代入するとひずみ成分は,

$$
\varepsilon_{i j}=\sum_{n=0}^{\infty} x_{3}^{n}\left(\varepsilon_{i j}^{(n)}+\bar{\varepsilon}_{i j}^{(n)}\right)
$$

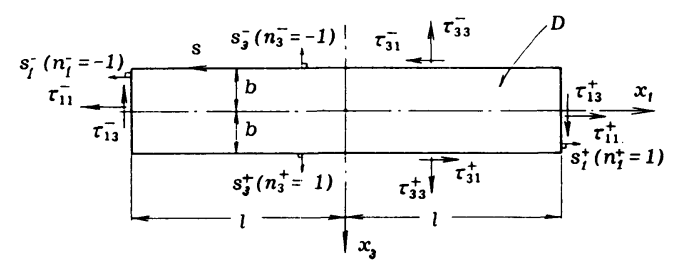

Fig. 1 Geometry of beam and the surface tractions.

$$
\begin{aligned}
& \text { ここに, } \\
& \left.\begin{array}{rl}
\varepsilon_{i j}^{(n)} & =\frac{1}{2}\left(\delta_{i 1} u_{j, 1}^{(n)}+\delta_{j 1} u_{i, 1}^{(n)}\right), \\
\bar{\varepsilon}_{i j}^{(n)} & =\frac{1}{2}(n+1)\left(\delta_{i 3} u_{J}^{(n+1)}+\delta_{j 3} u_{i}^{(n+1)}\right) .
\end{array}\right\}
\end{aligned}
$$

で求められることになる.上式中の $\delta_{i j}$ は Kronecker の deltaであり, コンマ (, ) の次の添字は, その添字のつ いた座標に関する偏微分を表わす。式（3）のひずみ成 分を一般化された構成関係式（応力ーひずみ関係）に代 入整理すると応力成分が変位係数を用いて次のように表 わされる.

$$
\tau_{i j}=\sum_{n=0}^{\infty} x_{3}^{n}\left\{C_{i j 1 l} u_{l, 1}^{(n)}+(n+1) C_{i j 3 l} u_{l}^{(n+1)}\right\}
$$

ここに, $C_{i j k l}$ は弾性定数である

さらに，この応力成分を用いて， $n$ 次の構成関係式（断 面力-変位係数関係) が次のように得られる.

$$
\begin{aligned}
\tau_{i j}^{(n)} & =\int_{-b}^{b} \tau_{i j} x_{3}^{n} d x_{3} \\
& =\sum_{m=0}^{\infty} B_{m n}\left\{C_{i J 1 l} u_{l, 1}^{(m)}+(m+1) C_{i j 3 l} u_{l}^{(m+1)}\right\}
\end{aligned}
$$

ここに,

$$
B_{m n}=\hat{\delta}_{m+n} \frac{2 b^{m+n+1}}{m+n+1}, \hat{\delta}_{m+n}=\frac{1}{2}\left\{1+(-1)^{m+n}\right\} \cdots
$$

なお，これらの成分と通常のはりの断面力との関係を挙 げれば, 次のようである.

$$
\begin{aligned}
& \tau_{11}^{(0)}=N: \text { 軸力 } \\
& \tau_{13}^{(0)}=Q: \text { せん断力 } \\
& \tau_{11}^{(1)}=M: \text { 曲げモーメント }
\end{aligned}
$$

上記以外の断面力 $\left(\tau_{i j}^{(n)}\right)$ は, 古典理論や Timoshenko 理論では現われない.

次にはりの運動方程式と境界条件式を Hamilton の原 理を用いて導くことにする.すなわち Fig. 1 に示すよう に外向き方向の法線ベクトル $\boldsymbol{n}$ をも表面 $s$ で井まれ た領域 $V$ 内において, 次式が成立する.

$$
\begin{aligned}
\delta \int_{\hat{t}_{0}}^{\hat{t}_{1}} d t \int_{V}(T-U) d V & +\int_{\hat{t}_{0}}^{\hat{t}_{1}} d t\left[\int_{s} t_{j} \delta u_{j} d s\right. \\
& \left.+\int_{V} f_{j} \delta u_{j} d V\right]=0 \cdots \cdots
\end{aligned}
$$

上式中の $T, U$ は単位体積当たりの運動エネルギーおよ びひずみエネルギーで，次式で与えられる。

$$
T=\frac{1}{2} \rho \dot{u}_{j} \dot{u}_{j}, \quad U=\frac{1}{2} C_{i j k l} \varepsilon_{i j} \varepsilon_{k l} .
$$

ここに, $\rho$ は密度であり, ドット（・）は時間 $t$ に関す る偏微分を表わす．また， $t$ および $f_{j}$ は単位表面積当 たりの表面力および単位体積当たりの物体力で, $t_{j}$ は 応力成分之次式の関係がある.

$$
t_{j}=n_{i} \tau_{i j}
$$

以下では上述の各式を用いて，奥行き方向に対して， 平面問題（奥行き $1, x_{1} x_{3}$ 面内での領域を $D$ とし，この $D$ を囲む周囲を $s$ とる.すなわち $V=1 \times D$, 
$S=1 \times s)$ としてはり問題の定式化を行う ${ }^{ \pm 11}$.

・ひずみエネルギー：

$\delta \int_{V} U d V=\int_{D} \tau_{i j} \delta \varepsilon_{i j} d D$

$=\sum_{n=0}^{\infty}\left[\int_{-l}^{l}\left\{-\tau_{1 j, 1}^{(n)}+n \tau_{3 j}^{(n-1)}\right\} \delta u_{j}^{(n)} d x_{1}+\left[\tau_{1 j}^{(n)} \delta u_{j}^{(n)}\right]_{-l}^{l}\right]$

・表面力および物体力：

$\int_{s} t_{j} \delta u_{j} d s+\int_{V} f_{j} \delta u_{j} d V$

$=\sum_{n=0}^{\infty}\left\{\int_{-l}^{l}\left[x_{3}^{n} \tau_{3 j}\right]_{-b}^{b} \delta u_{j}^{(n)} d x_{1}+\int_{-b}^{b}\left[x_{3}^{n} \tau_{1 j}\right]_{-l}^{l} \delta u_{j}^{(n)} d x_{3}\right.$ $+\int_{-l}^{l} \int_{-b}^{b} x_{3}^{n} f_{j} \delta u_{j} d x_{3} d x_{1}$

$=\sum_{n=0}^{\infty}\left\{\int_{-l}^{l}\left(F_{j}^{(n)}+f_{j}^{(n)}\right) \delta u_{j}^{(n)} d x_{1}+W_{j}^{(n)} \delta u_{j}^{(n)}\right\}$

ここに,

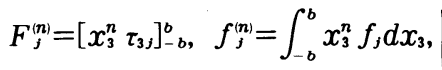

$\Psi_{j}^{(n)}=\int_{-b}^{b}\left[x_{3}^{n} \tau_{1 j}\right]_{-l}^{l} d x_{3}$.

・運動エネルギー：

$\delta \int_{\hat{t}_{0}}^{\hat{t}_{1}} d t \int_{V} T d V=\int_{\hat{t}_{0}}^{\hat{t}_{1}} d t \int_{-l}^{l} \int_{-b}^{b} \rho \dot{u}_{j} \delta \dot{u}_{j} d x_{3} d x_{1}$

$=-\sum_{m=0}^{\infty} \sum_{n=0}^{\infty} \int_{\hat{\varepsilon}_{0}}^{\hat{t}_{1}} d t \int_{-l}^{l} \rho^{(m, n)} \ddot{u}_{j}^{(m)} \delta u_{j}^{(n)} d x_{1}$

ここに,

$\rho^{(m, n)}=\int_{-b}^{b} \rho x_{3}^{m+n} d x_{3}$

式 (11)，(12)，(14）を式（8）に代入してまとめると, 奥行き方向に平面問題とした 1 次元化はり理論に関する Hamilton の原理は次式のようになる.

$$
\begin{aligned}
& \sum_{n=0}^{\infty} \int_{\hat{\tau}_{0}}^{\hat{t}^{1}} d t\left[\int _ { - l } ^ { l } \left\{\tau_{1 j, 1}^{(n)}-n \tau_{3 j}^{(n-1)}+F_{j}^{(n)}+f_{j}^{(n)}\right.\right. \\
& \left.\left.\left.-\sum_{m=0}^{\infty} \rho^{(m, n)} \ddot{u}_{j}^{(n)}\right\} \delta u_{j}^{(m)}\right\} \delta u_{j}^{(n)} d x_{1}+\left\{T_{j}^{(n)}-\left[\tau_{1 j}^{(n)}\right]_{-l}^{l}\right\} \delta u_{j}^{(n)}\right]
\end{aligned}
$$

上式より，はりの運動方程式および境界条件式が以下の ように与えられる.

$$
\begin{aligned}
& \tau_{1 j, 1}^{(n)}-n \tau_{3 j}^{(n-1)}+F_{j}^{(n)}+f_{j}^{(n)}=\sum_{m=0}^{\infty} \rho^{(m, n)} \ddot{u}_{j}^{(m)} \ldots \\
& T_{j}^{(n)}=\tau_{i j}^{(n)} \text { or } \quad \bar{u}_{j}^{(n)}=u_{j}^{(n)} \text { at } x_{1}= \pm l \cdots
\end{aligned}
$$

なお,ここで $\bar{u}_{j}^{(n)}$ は境界で規定されるべき変位 $\bar{u}$, と次 の関係をもつ変位係数である.

$$
\bar{u}_{j}=\sum_{n=0}^{\infty} x_{3}^{n} \bar{u}_{j}^{(n)}
$$

注1）この仮定は必ずしも必要ではなく，たとえば式 (17)〜 （21）に得られた基礎式における $B_{m n}$ [式（6）参照]を $B_{m n}=\int_{-b}^{b} \int_{x_{2}} x_{3}^{m+n} d x_{2} \cdot d x_{3}$

のように $(m+n)$ 次の断面モーメントと考えれば, 奥 行方向に任意に変化するような円，棈円，I型，箱型等 の任意の断面形の問題にもそのまま適用できる.
さて, 式（17）に式（5）を代入すると, 変位係数で 示したはりの運動方程式が, 次式のように求められる.

$$
\begin{aligned}
\sum_{m=0}^{\infty} & B_{m n}\left\{C_{1 j 1 l} u_{l, 11}^{(m)}+(m+1) C_{1 j 3 l} u_{l, 11}^{(m+1)}\right\} \\
& -n \sum_{m=0}^{\infty} B_{m, n-1}\left\{C_{3 j 1 l} u_{l, 1}^{(m)}+(m+1) C_{3 j 3 l} u_{l}^{(m+1)}\right\} \\
& +F_{j}^{(n)}+f_{j}^{(n)}=\rho \sum_{m=0}^{\infty} B_{m n} \ddot{u}_{j}^{(m)} \ldots \ldots \ldots \ldots \ldots \ldots \ldots
\end{aligned}
$$

上式は等質で最も一般的な異方性はりに対しても成立す るものであるが, 特別な場合として等方性のはりの運動 方程式は次のようになる。

$$
\begin{aligned}
& \sum_{m=0}^{\infty} B_{m n}\left\{(\lambda+2 G) \cdot u_{1,11}^{(m)}+[(m+1) \lambda-n G] u_{3,1}^{(m+1)\}}\right. \\
& -2 G \delta_{n}^{0} b^{n} u_{3,1}^{(0)}-n G \sum_{m=0}^{\infty} B_{m, n-1}(m+1) u_{1}^{(m+1)} \\
& +F_{1}^{(n)}+f_{1}^{(n)}=\rho \sum_{m=0}^{\infty} B_{m n} \ddot{u}_{1}^{(m)}, \\
& \sum_{m=0}^{\infty} B_{m n}\left\{G u_{3,11}^{(m)}+[(m+1) G-n \lambda] u_{1,1}^{(m+1)}\right\}-2 \lambda \delta_{n}^{0} b^{n} u_{1,1}^{(0)} \\
& -n(\lambda+2 G) \sum_{m=0}^{\infty} B_{m, n-1}(m+1) u_{3}^{(m+1)}+F_{3}^{(n)}+f_{3}^{(n)} \\
& =\rho \sum_{m=0}^{\infty} B_{m n} \ddot{u}_{3}^{(m)}
\end{aligned}
$$

ここに, $\lambda, G$ は Lamé の定数で弾性係数 $E$, ポアソン 比レにより，次式で与えられる.

$$
\lambda=\frac{\nu E}{(1+\nu)(1-2 \nu)}, \quad G=\frac{E}{2(1+\nu)}
$$

また， $\delta_{n}^{0}$ は次のような記号である.

$$
\delta_{n}^{0}=\frac{1}{2}\left\{1-(-1)^{n}\right\}
$$

なお, 等方性の場合で, 奥行き方向に関し, 平面応力問

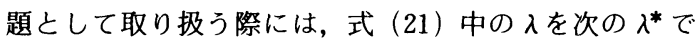
置き換えてやればよい.

$$
\lambda^{*}=\frac{\nu E}{1-\nu^{2}}
$$

さらに, 等質なはりでは, はりの伸縮挙動と曲げ挙動と は，互いに連成せず，支配方程式は独立な 2 群の連立常 微分方程式を形成するが，その具体式を書き出すことは 省略する。

\section{3. 一般化高次はり理論の特殊化と他のいくつ かのはり理論との関係}

ここでは,前節に示した一般化高次はり理論において, 低次のいくつかの項を採用した場合の支配方程式を示 し，それを特殊化することによって，他のいくつかのは り理論の式が得られることおよび, 従来提案されている 代表的なはり理論と本理論との関係について検討する. なお, 以下でははりは等方性で, 荷重ははり上面に鉛直 下向に $p=p(x, t)$ のみが載荷されるものとし, 物体力 は無視する.

まず, 変位係数として, $u_{1}^{(0)} \sim u_{1}^{(3)}, u_{3}^{(0)} \sim u_{3}^{(2)}$ の 7 個を 
採用した場合 ${ }^{(12)}$ について，支配方程式の具体形を示せ ば以下のようになる（紙面の都合上，伸縮挙動の式は省 略).

\section{曲げ挙動：}

$2 b G\left(u_{3,11}^{(0)}+u_{1,1}^{(1)}\right)+\frac{2}{3} b^{3} G\left(u_{3,11}^{(2)}+3 u_{1,1}^{(3)}\right)+p$ $=2 b \rho \ddot{u}_{3}^{(0)}+\frac{2}{3} b^{3} \rho \ddot{u}_{3}^{(2)}$,

$\frac{2}{3} b^{3}\left\{(\lambda+2 G) u_{1,11}^{(1)}+(2 \lambda-G) u_{3,1}^{(2,}\right\}-2 b G u_{3,1}^{(0)}-2 b G u_{1}^{(1)}$ $+\frac{2}{5} b^{5}(\lambda+2 G) u_{1,11}^{(3)}-2 b^{3} G u_{1}^{(3)}=\frac{2}{3} b^{3} \rho \ddot{u}_{1}^{(1)}+\frac{2}{5} b^{5} \rho \ddot{u}_{1}^{(3)}$, $\frac{2}{3} b^{3}\left\{G u_{3,11}^{(0)}+(G-2 \lambda) u_{1,2}^{(1)}\right\}-\frac{8}{3} b^{3}(\lambda+2 G) u_{3}^{(2)}+b^{2} p$ $+\frac{2}{5} b^{5}\left\{G u_{3,11}^{(2)}+(3 G-2 \lambda) u_{1,1}^{(3)}\right\}=\frac{2}{3} b^{3} \rho \ddot{u}_{3}^{(0)}+\frac{2}{5} b^{5} \rho \ddot{u}_{3}^{(2)}$, $\frac{2}{5} b^{5}\left\{(\lambda+2 G) u_{1,11}^{(1)}+(2 \lambda-3 G) u_{3,1}^{(2)}\right\}-2 b^{3} G u_{3,1}^{(0)}-2 b^{3} G u_{1}^{(1)}$ $+\frac{2}{7} b^{7}(\lambda+2 G) u_{1,11}^{(3)}-\frac{18}{5} b^{5} G u_{1}^{(3)}=\frac{2}{5} b^{5} \rho \ddot{u}_{1}^{(1)}+\frac{2}{7} b^{7} \rho \ddot{u}_{1}^{(3)}$.

また，これらを解くための境界条件式は次の式 (26) (28) で与えられる.

a) 固定支持端

- 曲げ挙動 : $u_{3}^{(0)}=u_{3}^{(2)}=u_{1}^{(1)}=u_{1}^{(3)}=0$,

- 伸縮挙動: $u_{1}^{(0)}=u_{1}^{(2)}=u_{3}^{(1)}=0$.

b) 単純支持端

- 曲げ挙動： $u_{3}^{(0)}=u_{3}^{(2)}=0, \quad \tau_{11}^{(1)}=\tau_{11}^{(3)}=0$,

- 伸縮挙動： $\tau_{11}^{(0)}=\tau_{11}^{(2)}=\tau_{33}^{(1)}=0$.

c) 自由端

-曲げ挙動： $\tau_{13}^{(0)}=\tau_{13}^{(2)}=0, \quad \tau_{11}^{(1)}=\tau_{11}^{(3)}=0$,

- 伸縮挙動 $: \tau_{11}^{(0)}=\tau_{11}^{(2)}=\tau_{33}^{(1)}=0$.

ところで, 上記の支配方程式において, 静的問題に限定 し，また伸縮挙動を無視して曲げ挙動のみに着目，すな わち, $p$ を静何重とし, 時間 $t$ での微分項をすべて削 除し, 変位係数として $u_{1}^{(1)}, u_{1}^{(3)}, u_{3}^{(0)}, u_{3}^{(2)}$ の 4 項のみを採 用すると,これらはGupta \& Pathak 理論5)の支配方程 式に完全に一致する.

次に, 変位係数として $u_{1}^{(1)}, u_{3}^{(0)}$ のみを採用し, 奥行き 方向に平面応力問題として定式化を行えば,

$$
\begin{aligned}
& 2 b G\left(u_{3,11}^{(0)}+u_{1,1}^{(1)}\right)+p=2 b \rho \ddot{u}_{3}^{(0)}, \\
& \frac{2}{3} b^{3}\left(\lambda^{*}+2 G\right) u_{1,11}^{(1)}-2 b G\left(u_{3,1}^{(0)}+u_{1}^{(1)}\right)=\frac{2}{3} b^{3} \rho \ddot{u}_{1}^{(1)} .
\end{aligned}
$$

となるが,ここで, 平面応力問題における構成関係式に $\tau_{33}=0$ の仮定, およびせん断補正係数 $x^{2}$ を導入した式：

$$
\tau_{11}=E \varepsilon_{11}, \quad \tau_{13}=\chi^{2} G \varepsilon_{13},
$$

注2）これらの変位係数を採用した理由は, 文献8)の平板理 論における P-3 order の変位場の仮定,ならびに文献6) の平板理論における変位係数に準じたもので，せん断応 力が $x_{3}$ の 2 次式にそろえられている.

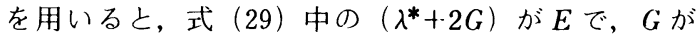
$x^{2} G$ でそれぞれ置き換えられた式が得られる。 この式を わかりやすくするために，さらに $2 b \equiv A, 2 / 3 b^{3} \equiv I$, $u_{3}^{(0)} \equiv w, \quad u_{1}^{(1)} \equiv \psi$ の表現を用いて書き変えれば, 最終的 に次式を得る.

$$
\begin{aligned}
& \varkappa^{2} G A\left(w^{\prime \prime}+\psi^{\prime}\right)+p=\rho A \ddot{w} . \\
& E I \psi^{\prime \prime}-\varkappa^{2} G A\left(w^{\prime}+\psi\right)=\rho I \ddot{\psi} .
\end{aligned}
$$

これは, 著名な Timoshenkoのはり理論 ${ }^{1,2)}$ の支配方程 式である。なお，プライム記号は座標 $x_{1}$ に関する微分 を表わす。

一方，上記の例と同様に変位係数 $u_{1}^{(1)}, u_{3}^{(0)}$ を採用した 式 (29) において, せん断変形なし $\left(u_{1}^{(1)}=-u_{3,1}^{(0)}\right)$ の付 帯条件をつけることにより $u_{1}^{(1)}$ を消去すれば次式が求め られる.

$\frac{2}{3} b^{3}\left(\lambda^{*}+2 G\right) u_{3,1111}^{(0)}-p=-2 b \rho \ddot{u}_{3}^{(0)}+\frac{2}{3} b^{3} \rho \ddot{u}_{3,11}^{(0)}$

ここで前の例と同様の一軸応力状態の構成関係式 (30) を用い， $u_{3}^{(0)} \equiv w$ と書き変えれば次式を得る.

$E I w^{\prime \prime \prime \prime}=p-\rho A \ddot{w}+\rho I \ddot{w}^{\prime \prime}$.

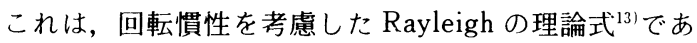
る.

最後に, 変位係数 $u_{3}^{(0)}, u_{1}^{(1)}\left(=-u_{3,3}^{(0)}\right)$ を採用し, 回転慣 性項を無視 $\left(\rho I \ddot{u}_{1}^{(1)}=0\right)$ すれば, 次の古典はり理論の運 動方程式が得られる.

$E I w^{\prime \prime \prime \prime}=p-\rho A \ddot{w}$.

\section{4. 各種のせん断変形を考慮したはり理論の概 要}

ここでは, 応力仮定型の平板曲げの理論をはりの問題 に適用したいくつかの理論の導出を試みる．まず，各種 理論の系統的な把握ができることから Baluch \& Voyiadjis 理論》に著者らの改良を加えた修正 Baluch \& Voyiadjis 理論) のはりへの適用について述べる.なお, ここでの座標系および荷重は, 通常の平板やはり理論の それに準じて Fig. 2 のようにとるものとする(すなわち， $x_{1}=x, x_{3}=z, \tau_{11}=\sigma_{x}, \tau_{33}=\sigma_{z}, \tau_{13}=\tau_{x z}, u_{1}=u_{x}, u_{3}=u_{z}$, etc. ).

まず，はりのせん断応力を，せん断力 $Q$ を用いて，

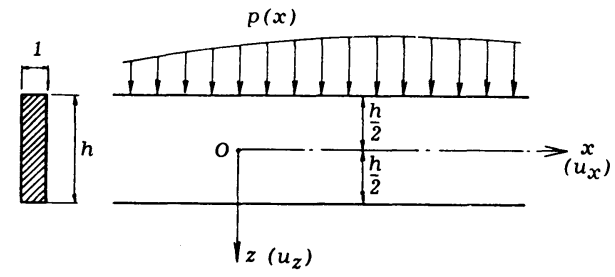

Fig. 2 Coordinates of beam and the upper surface load. 


$$
\tau_{x z}=\frac{3}{2 A} Q\left\{1-\left(\frac{2 z}{h}\right)^{2}\right\}
$$

と仮定し, 鉛直方向の力のつり合いと, はりの上下表面 での境界条件より, 高さ方向の直応力：

$$
\sigma_{z}=-\frac{p}{4}\left\{2-3\left(\frac{2 z}{h}\right)+\left(\frac{2 z}{h}\right)^{3}\right\}
$$

を得る。ここで軸方向直応力 $\sigma_{x}$ は軸力 $N$ および曲げ モーメント $M$ を用いて次式で表わされるものとする.

$$
\sigma_{x}=\frac{M}{I} z+\frac{N}{A}
$$

これらの $\sigma_{z}, \sigma_{x}$ を用いて, 奥行き方向の直応力 $\sigma_{y} \equiv 0$ の 平面応力状態を仮定して定式化を行えば，幾何学的関係 式および構成関係式より, 高さ方向の直ひずみに関する 次式を得る.

$$
\varepsilon_{z}=u_{z z}=-\frac{1}{E} \sigma_{z}-\frac{\nu}{E A} N-\frac{\nu z}{E . I} M .
$$

これより, 鉛直方向変位 $u_{z}$ が次のように求まる.

$$
\begin{aligned}
u_{z}=w-\frac{\nu}{E A} & N z-\frac{\nu}{2 E I} M z^{2}-\frac{p}{4 E}\left\{2 z-\left(\frac{3 z^{2}}{h^{3}}\right)\right. \\
& \left.+\left(\frac{4 z^{4}}{h^{3}}\right)\right\} \quad \ldots \ldots \ldots \ldots \ldots \ldots \ldots \ldots \ldots \ldots \ldots \ldots \ldots \ldots
\end{aligned}
$$

一方，前に仮定した $\tau_{x z}$ を用いると，せん断ひずみに関 する次式が得られる.

$$
\gamma_{x z}=u_{z, x}+u_{x, z}=\frac{3 Q}{2 G A}\left\{1-\left(\frac{2 z}{h}\right)^{2}\right\}
$$

これに式（39）を代入し，積分を実行すれば，軸方向変 位 $u_{x}$ が,

$$
\begin{aligned}
u_{x}= & u-z w,_{x}+\frac{z}{2 G A}\left\{3-\left(\frac{2 z}{h}\right)^{2}\right\} Q+\frac{\nu z^{2}}{2 E A} N,,_{x} \\
& +\frac{\nu z^{3}}{6 E I} M,_{x}+\frac{p, x}{4 E}\left\{z^{2}-\left(\frac{z^{3}}{h}\right)+\left(\frac{2 z^{5}}{5 h^{3}}\right)\right\} . \cdot(41)^{(i \pm 3)}
\end{aligned}
$$

のように求まる.これから幾何学的関係式 $\varepsilon_{x}=u_{x, x}$ を 用いて，軸方向直ひずみ $\varepsilon_{x}$ を求め，構成関係式 $\left(\sigma_{x}=E \varepsilon_{x}+\nu \sigma_{z}\right)$ より $\sigma_{x}$ を求めれば次のようになる.

$$
\begin{aligned}
\sigma_{x}= & E\left[u,_{x}-z w_{, x x}+\frac{z}{2 G A}\left\{3-\left(\frac{2 z}{h}\right)^{2}\right\} Q,{ }_{x}+\frac{\nu z^{2}}{2 E A} N,_{x x}\right. \\
& \left.+\frac{\nu z^{3}}{6 E I} M_{, x x}+\frac{p, x x}{4 E}\left\{z^{2}-\left(\frac{z^{3}}{h}\right)+\left(\frac{2 z^{5}}{5 h^{3}}\right)\right\}\right] \\
& -\frac{\nu p}{4}\left\{2-3\left(\frac{2 z}{h}\right)+\left(\frac{2 z}{h}\right)^{3}\right\} \cdots \cdots \cdots \cdots(42)
\end{aligned}
$$

以上のように求められた $\sigma_{x}$ および $\tau_{x z}$ を用いて,

$$
(N, M, Q)=\int_{A}\left(\sigma_{x}, \sigma_{x z}, \tau_{x z}\right) d A
$$

より断面力を求め, 運動方程式を断面積分して得られる 断面力の運動方程式に前記の変位成分とともに代入すれ ば，はりの運動方程式が最終的に次式のように求まる. 曲げ挙動：

注3） $w, u$ はおのおの, 中立軸位置における軸直角方向（高 さ方向）および軸方向の変位である. したがって前節の 変位係数とは $u_{1}^{(0)}=u, u_{3}^{(0)}=w$ の関係がある.

$$
\begin{aligned}
& Q,,_{x}+p=\rho A \ddot{w}-\frac{\nu \rho}{2 E} \ddot{M}+\frac{9 \rho h^{2}}{160 E} \ddot{p}, \\
& -E I w, x x x+\frac{E h^{2}}{10 G} Q, x x-Q+\frac{\nu h^{2}}{40} M, x_{x x}+\frac{13 h^{4}}{4480} p, x x x \\
& +\frac{\nu h^{2}}{10} p, x=-\rho I \ddot{w}_{, x}+\frac{\rho h^{2}}{10 G} \ddot{Q}+\frac{\nu \rho h^{2}}{40} \ddot{M},_{x}+\frac{13 \rho h^{4}}{4480 E} \ddot{p},_{x} \\
& M=-E I w, x x+\frac{E h^{2}}{10 G} Q, x+\frac{\nu h^{2}}{40} M, x x \\
& +\frac{13 h^{4}}{4480} p,,_{x x}+\frac{\nu h^{2}}{10} p
\end{aligned}
$$

伸縮挙動：

$$
\begin{array}{r}
E A u_{, x x}+\frac{\nu h^{2}}{24} N,_{x x x}+\frac{\nu h^{3}}{48} p,,_{x x x}-\frac{\nu h}{2} p,,_{x} \\
=\rho A \ddot{u}+\frac{\nu \rho h^{2}}{24 E} \ddot{N}_{, x}+\frac{\rho h^{3}}{48 E} \ddot{p},_{x} \\
N=E A u,_{x}+\frac{\nu h^{2}}{24} N,_{x x}+\frac{\nu h^{3}}{48} p,_{x x}-\frac{\nu h}{2} p \cdots \cdots
\end{array}
$$

また，その他の理論は次のようにして得られる.

まずここに示した式の誘導過程において，式（38）の 右辺の第 1 項を無視，すなわち $\varepsilon_{z}$ としては軸力と曲げ モ一メントによる効果のみを取り上げ, 直応力 $\sigma_{z}$ によ る $\varepsilon_{z}$ への効果は無視し, それ以降の定式化を行えば Rehfield \& Murthy の理論 ${ }^{3)}$ が得られる。一方, 軸力 $N$ の効果を無視すれば Baluch \& Voyiadjis 理論")をはり へ適用したものになり,さらに $\varepsilon_{z}$ の効果を無視したも のは Ambartsumyan 理論" をはりに適用した理論に，ま たさらに $\sigma_{z}$ の影響をも無視すれば, Schmidtの平板理 論 ${ }^{10)}$ の線形化をはかりはりに適用したものとなる.なお, これらの理論の動的な支配方程式および変位, 応力の式 を他の代表的なはり理論である Timoshenko 理論 ${ }^{1), 2)}$, Levinson 理論 ${ }^{11}$ とともに，比較表にまとめたものが付 録Aに与えられている.

\section{5. 計 算 例}

ここでは, 静的な 2 つの基本的なはりの問題 (等分布 荷重を満載した単純ばりおよび先端に集中荷重を受ける 片持ちばり) ならびに動的な問題（単純支持ばりの固有 振動スペクトルおよび無限長のはりの分散関係）を取り 上げ，前節で略述した各種はり理論による計算結果の比 較を行うことにする. まず最初に静的な問題に対して得 られた解のうち, 変位 $u_{x}, u_{z}$ および応力 $\sigma_{x}$ についての 結果を古典理論による解ならびに 2 次元弾性論による

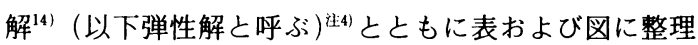

注4）たとえば (A) の場合には，はりの両端面で断面力に 対し $M=N=0, Q=q L / 2$ という条件を設定したものであ り, (B)|の場合には先端部で断面力に対し $M=N=0, Q=Q_{0}$ を, 固定端部においては $x=L, z=0$ の一点において $u_{x}, u_{z}=u_{x, z}=0$ の条件を満たすようにし てべキ級数解を求めたものを弾性解と呼ぶことにする. 
して比較することによって，各理論の相互関係について 考察する。なおこここでは次の各理論に対し（）内に 示す略号を用いる. Timoshenko 理論 ( $\mathrm{T}$-理論), Levinson 理論 (L-理論), Schmidt 理論 (S-理論), Ambartsumyan 理論 (A-理論), Baluch \& Voyiadjis 理論 (B. V-理論), 修正 Baluch \& Voyiadjis 理論 (Ref. B. V-理論), Rehfield \& Murthy 理論 (R. M-理論), 一般化高次理論 (G. H. - 理論), Gupta \& Pathak 理論 (G. P. - 理論).

\section{（A）上表面に等分布荷重 $q$ を满載した単純ばり}

$x= \pm L / 2$ で単純支持された長さ $L$ のはりに等分布 荷重 $q$ が載った問題に対する解として変位成分 $u_{z}, u_{x}$ および曲げ応力 $\sigma_{x}$ が 2 次元弾性解 ${ }^{14}$ については次式で 与えられる $\left(x^{2}, \alpha, \beta, \gamma\right.$ 等の值は Table 1 に与えられて (る).

$$
\begin{array}{r}
\begin{array}{r}
u_{z}=\frac{5 q L^{4}}{384 E I}\left\{1+\frac{8}{5 x^{2}}(1+\alpha \nu)\left(\frac{h}{L}\right)^{2}\right\}+\frac{q}{2 E I}\left\{\frac{x^{4}}{12}-\frac{L^{2} x^{2}}{8}\right. \\
-\frac{h^{2} x^{2}}{6 x^{2}}(1+\alpha \nu)-\left(\frac{h^{3} z}{12}-\frac{h^{2} z^{2}}{8}+\frac{z^{4}}{12}\right) \\
\left.-\nu\left[\left(\frac{L^{2}}{4}-x^{2}\right) \frac{z^{2}}{2}+\frac{z^{4}}{6}-\frac{h^{2} z^{2}}{20}\right]\right\}, \\
u_{x}=\frac{q}{2 E I}\left\{\left(\frac{L^{2} x}{4}-\frac{x^{3}}{3}\right) z+(1+\beta \nu) x\left(\frac{2 z^{3}}{3}-\frac{h^{2} z}{10}\right)\right. \\
\left.-\ldots \nu \frac{2 h^{2}}{5} z+\frac{\nu h^{3}}{12} x\right\} \\
-(5)\left(20 z^{3}-3 h^{2} z\right) .
\end{array} \\
\sigma_{x}=\frac{q}{8 I}\left(L^{2}-4 x^{2}\right) z+\frac{q}{60 I}(1+\gamma \nu)(3)
\end{array}
$$

その他の理論の解は上式中の下線項を Table 1 に示すよ うに適宜，削除した結果によって求められる．この結果 から，次のようなことがいえる.

(1) 古典理論と T-理論による結果においては, 鉛直 変位 $u_{z}$ に関して，後者にせん断変形によるたわみ分が 考慮されている以外は, 変位 $u_{x}$ 応力 $\sigma_{x}$ とも同一であ る.

\begin{tabular}{|c|c|c|c|c|c|}
\hline Theory & Adopting terms & $k^{2}$ & $\alpha$ & $\beta$ & $\gamma$ \\
\hline 2D Elast. theory & all terms & $5 / 6$ & $5 / 8$ & $1 / 2$ & 0.0 \\
\hline $\left.\begin{array}{c}\operatorname{Ref} . \mathrm{B} \cdot \mathrm{V}-\mathrm{v} \\
\text { B.V-theories }\end{array}\right\}$ & neglect (1) & - & $*$ & $\sim$ & " \\
\hline R.M-theory & neglect (1) \& (2) & - & • & 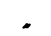 & " \\
\hline A-theory & neglect (1) (3) & ^ & $*$ & 1.0 & $1 / 2$ \\
\hline L- \& S-theories & neglect (1) (4) & - & $1 / 2$ & * & 1.0 \\
\hline$T$-theory & neglect (1) (5) & 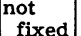 & 1.0 & - & - \\
\hline Classical theory & neglect (1) (6) & - & - & - & - \\
\hline
\end{tabular}

(2) T-理論での， $u_{z}$ におけるせん断補正係数 $\boldsymbol{x}^{2}$ を $5 / 6$ とおけば，L- 理論でのそれに一致する11).

Table $1 u_{x}, u_{z}$ and $\sigma_{x}$ given by eq. (46) due to the various theories for simply-supported beam under uniform load $q_{0}$.
(3) L- 理論での $u_{z}$ およ゙応力 $\sigma_{x}$ の式におけるポア ソン比 $\nu を \nu / 2 て ゙$ 置き換えれば，A-理論での $u_{z}$ およ び $\sigma_{x}$ にそれぞれ一致する.

(4) Ref. B. V-理論およびR. M-理論による解は，変 位 $u_{x}$ と応力 $\sigma_{x}$ に関しては弾性解と一致するが，変位 $u_{z}$ において，はりの高さ方向の変化を表わす項に若干 の差異を生ずる.これは Ref. B. V-理論において，初期 值 $\sigma_{x}$ として仮定したものが弾性解の $\sigma_{x}$ と異なっている

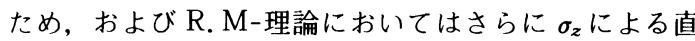
ひずみ分を無視しているために生ずるものである.

(5) $\mathrm{L}$-理論と $\mathrm{S}$-理論との結果は, たわみ $w$, 変位 $u_{x}$, 応力 $\sigma_{x}$ とも全く同一となる.

これらは荷重が等分布であるために生ずるものであ り，他の一般的な荷重状態のもとでは付録 Aの一般式に みられるように差異が生じる。

\section{（B）先端に集中荷重 $Q_{0}$ を受ける片持ちばり}

$x=0$ に集中荷重 $Q_{0}$ を載荷し， $x=L$ を固定支持され たはりの問題に対する解として $u_{z}, u_{x}$ および $\sigma_{x}$ が 2 次 元弾性解, Ref. B. V-理論, B. V-理論, R. M-理論に対 して全く同一であって次式で与えられる.

$$
\begin{aligned}
& u_{z}=\frac{Q_{0}}{6 E I}\left\{\left(x^{3}-3 L^{2} x+2 L^{3}\right)+\frac{E h}{2 x^{2} G}(L-x)+3 \nu x z^{2}\right\}, \\
& u_{x}=-\frac{Q_{0}}{2 E I}\left\{\left(x^{2}-L^{2}\right) z-\frac{E}{3 G} z^{3}+\frac{\nu}{3} z^{3}\right\} \\
& \sigma_{x}=\frac{Q_{0}}{I} x z
\end{aligned}
$$

その他の理論は上式中の項を Table 2 に示すように特殊 化すれば求められる．この結果より次のようなことがい える.

(1) 曲げ応力 $\sigma_{x}$ に対しては, 古典理論から弾性解ま ですべて同一の結果が得られる.

(2) L- 理論, S-理論, A-理論の 3 者は, 変位 $u_{z}$ $\left(\varepsilon_{x} \equiv 0\right.$ より, たわみ $w$ に等しい $), u_{x}$ および応力 $\sigma_{x}$ の すべてに関して同一の解を与える。

(3) Ref, B. V-理論およびR. M-理論による解は，変 位 $u_{z}, u_{x}$, 応力 $\sigma_{x}$ とも, 弾性解に一致している.

(4) 古典理論と $\mathrm{T}$-理論とでは，たわみ $w$ に対する解 において T-理論にせん断変形の効果が入り多少異なる

Table $2 u_{x}, u_{z}$ and $\sigma_{x}$ given by eq. (47) due to the various theories for cantilever beam under concentrated load $Q_{0}$ at free edge.

\begin{tabular}{|l|l|c|}
\hline \multicolumn{1}{|c|}{ Theory } & Adopting terms & $x^{2}$ \\
\hline 2D Elast., Ref.B.V- & all terms & $2 / 3$ \\
B.V- \& R.M-theories & neglect (1) & \\
A-, L- \& S-theories & not \\
T-theory & fixed \\
Classical theory & neglect (1) \& (2) & - \\
\hline
\end{tabular}


ほかは $u_{x}, \sigma_{x}$ とも全く同じ結果となる.

(5) T-理論での $\boldsymbol{w}$ におけるせん断補正係数 $\boldsymbol{x}^{2}$ を $2 / 3$ とおいた場合が L-, S-, A-理論でのたわみと一致する.

以上の結果，ここで比較の対象とした解が， 2 次元弾 性論による解，すなわち例題 (A)，(B) ともにRef. B. $\mathrm{V}-$ 理論のレベルでカバーできる次数の解であったため に，この解は (B) では完全に弾性解に一致し，(A) においてもかなりよい近似解が得られた。また式の上で の定性的な比較において, その他の理論における解も, 考慮する力学量に伴い, 順次両者の解に近づいてゆく傾 向を示した。ただし，この弾性解は脚注 4$)$ に述べたよ うに端面での特殊な境界条件のもとでのみ，厳密解にな り得るものであることを考慮しておく必要がある.

以上では各種理論の解のもつ定性的な比較結果を要約

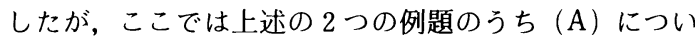
ての数值例を示したのが Fig. 3,4である.なお，ここで は厳密なはりの挙動を知る一つの試みとして Pagano ${ }^{121}$ が， 2 対辺を単純支持された一方向の無限平板の円筒曲 げの問題を解いた厳密解法 ${ }^{25}$ を平面応力状態のはりに 適用して得た解析結果と各種はり理論によるものとの比 較を行う。なおここに示す数値例におけるはりの諸元 は，各理論間の差異がある程度䫓著になるように $h / L$ の十分大きい場合，すなわち $h / L=0.75$, ポアソン比 $\nu=0.3$ のものであり, G. H. - 理論 (5 order) と Pagano 理論 ${ }^{12}$ では等分布荷重を Fourier 級数に展開 (101 項採用) して計算 ${ }^{8)} し ， そ の$ 他の理論では式 (46) および Table 1 に示した結果に基づいて数値計算を実施 したものである.

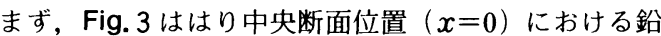
直方向変位 $u_{z}$ の高さ方向の分布を示している．この問 題では荷重の上下非対称性からもわかるとおり，実際の はりの鉛直方向変位は上で大きく，下で小さい非対称分 布となるが，この傾向を表わし得るのは次の 4 種の理論 であり，そのうち G. H. - 理論は Pagano 理論と同一線 で表わされ，これらより多少大きめの値を示す B. V-理 論は 2 次元弾性解にほぼ等しい値を与える.

一方，他のはり理論による値は，はりの曲げ挙動のみ しか考慮していないため，上下対称な分布を与え，高さ 方向に直線変化の直ひずみの存在を考慮した R.M-理 論および G.P-理論が $z=0$ の中心軸に関し対称な 2 次 放物線分布の変位を示す以外は，いずれも高さ方向に一 定値の変化を与える.このうち，A-理論での値は前述 のより正確な 4 種の理論の值を平均化した値を示し L-

注 5）脚注 4 ）に示した 2 次元弾性解の巨視的な力学的境界 条件 $(M=N=0)$ とは異なり，支持端面 $x= \pm L / 2$ に おいてすべての $z$ の值に対して $\sigma_{x}=0$ の条件が完全に満 たされるように構成した解析理論である.

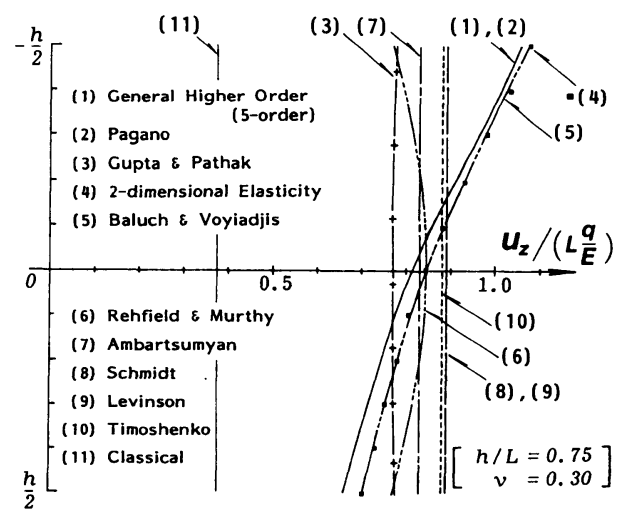

Fig. 3 Displacement $u_{z}$ along the vertical $z$-axis at the central cross-section for the case of simply supported beam under the uniform load $q$.

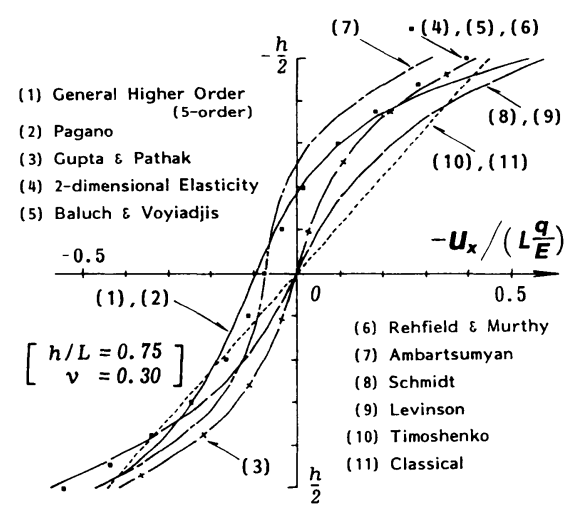

Fig. 4 Displacement $u_{x}$ along the vertical $z$-axis at the supported portion for the same case as Fig. 3 .

理論と T-理論とはこれらより平均値的に大きめの値を 与える. G. P-理論はこれらより小さめのほぼ直線に近 い分布を示す。また，古典理論はこれらの值の約半分以 下の值を与えるにすぎない。なお，R.M-理論は，定性 的に B. V-理論での鉛直変位における高さ方向直応力に 起因する直ひずみ分を高次微分項として無視したものと の性格づけができるが，この無視がここではかなりの精 度低下を招く要因となっている.

Fig. 4 ははり端部 $(x=L / 2)$ における軸方向変位 $u_{x}$ の高さ方向分布を示している．まず，G.H. - 理論の值 はPagano 理論での値と同じ曲線上にあり，はりの軸方 向伸縮挙動を考慮した結果として上下非逆対称な分布を 示し，またその最大変位ははりの上縁の載荷面位置で生 じている.これらは前述の高さ方向変位に関する考察と 同様平面応力状態とみなせる場合の実際のはりの挙動を 表わしていると思われる.このほかの非逆対称な分布を 示す理論では B. V-理論，R.M-理論はTable 1 からも わかるとおり 2 次元弾性解と全く同様な值を示してお 
り，また A-理論は独自な変位分布を示している。これ らの理論の最大変位は下縁の非載荷面位置で生じている が，これは前述の G. H. - 理論ならびに Pagano 理論と 大きく異なる点である.

以上の 6 種の理論以外は, いずれも上下逆対称な変位 分布を示し，そのうち G.P-理論および L- 理論が 3 次 分布を示す一方, $\mathrm{T}$-理論は古典理論と全く等しく, 直 線分布となる. また，これらの理論では上下縁で值が等 しく向きが逆の最大変位を生じている.

なお, 以上述べた各種理論間の差異は, はりの形状比 $h / L$ の值の減少に伴って急激に小さくなってゆき古典 理論とほぼ同等の値を示すようになる.

(C) 単純ばりの自由振動と無限長ばりの分散解析 ${ }^{1: 6)}$ 次に動的な問題の計算例として, 単純ばりの自由振動 と, 無限長ばり内を伝播する波動の分散関係を解析した 結果について述べる.

まず, 単純ばりの自由振動解における無次元化固有振 動数は

$$
\begin{aligned}
& \bar{\lambda}^{2}=\frac{\lambda^{2}}{\varphi^{2}}=\omega^{2} /\left(\frac{\pi}{h} \sqrt{\frac{E}{\rho}}\right)^{2} \varphi^{2}=\frac{1}{2 K_{0}}\left\{\frac{K_{1}}{\varphi^{2}}+K_{2}\right. \\
& \left. \pm \sqrt{\left(\frac{K_{1}}{\varphi^{2}}+K_{2}\right)^{2}-4 K_{0}^{2}}\right) \\
& K_{0}=\frac{E}{\varkappa^{2} G}+\frac{3 \nu}{10}, K_{1}=\frac{12}{\pi^{2}}, K_{2}=1+\frac{E}{\varkappa^{2} G}-\alpha \nu+\frac{3 \nu}{10} \text {. }
\end{aligned}
$$

で与えられる.ここに $\omega$ ははりの曲げ振動の固有円振 動数であり, $\varphi(=n h / L)$ はモードパラメーターで $n$ は 振動次数を表わす. 各種はり理論の結果は.上式を Table 3のように特殊化したもので与えられる.

他方, Rayleigh および古典の両理論での結果は以下 の式で示され， $c_{0}=1$ としたものが Rayleigh 理論 ${ }^{13)}$ で あり $c_{0}=0$ としたものが古典理論となる。

$$
\bar{\lambda}^{2}=\frac{\varphi^{2}}{K_{1}+c_{0} \varphi^{2}}
$$

次に無限長ばり内を伝播する SV 波の分散解析におけ る無次元化位相速度パラメーターは式（49）の表示を用

\begin{tabular}{|c|c|c|c|}
\hline Theory & Adopting terms & $x^{2}$ & $\alpha$ \\
\hline Ref.B.V-theory & all terms & $5 / 6$ & $1 / 2$ \\
\hline $\left.\begin{array}{r}\text { B.V-, } \\
\text { A-theories }\end{array}\right\}$ & neglect (1) & - & $1 / 5$ \\
\hline $\mathrm{L}-\mathrm{S}$ - theories & neglect (1) \& (2) & " & 一 \\
\hline$T$ - theory & - & not fixed & - \\
\hline
\end{tabular}

Table 3 Expressions of phase velocity and eigenfrequency given by eqs. (48), (50) and (51) due to the various beam theories.

注6）解析過程の詳細は著者らの論文 8) 2で奥行方向の座標 $y$ に関する項を適切に省略することにより求められるの で,ここでは述べない。
いれば, 次式で与えられる.

$$
\begin{array}{r}
\bar{C}^{2}=\frac{C_{\phi}^{2}}{C_{B}^{2}}=\frac{\omega^{2}}{\left(\frac{\pi}{h} \sqrt{\left.\frac{E_{2}}{\rho}\right)^{2} \bar{k}^{2}}\right.}=\frac{\Omega^{2}}{\bar{k}^{2}}=\frac{1}{2 K_{0}}\left\{\frac{K_{1}}{\bar{k}^{2}}+K_{2}\right. \\
\left. \pm \sqrt{\left(\frac{K_{1}}{\bar{k}^{2}}+K_{2}\right)^{2}-4 K_{0}^{2}}\right\} \cdots \cdots
\end{array}
$$

ここに, $\omega, k, C_{\varphi}$ はそれぞれ波動の固有円振動数, 波数 および位相速度であり, $C_{B}(=\sqrt{E / \rho})$ は無限長ばり内を 伝播する伸縮波の位相速度, $\bar{k}(=k h / \pi)$ は無次元化波数 パラメーターである.なお式中の $\Omega(=\bar{C} \bar{k})$ は無次元化 固有振動パラメーターと呼ばれるものである.

他方, Rayleigh 理論と古典理論での值は

$$
\bar{C}^{2}=\frac{\bar{k}^{2}}{K_{1}+c_{0} \bar{k}^{2}}
$$

で与えられ,これらの式で $C_{0}=1$ とすれば Rayleigh 理 論, $C_{0}=0$ とすれば古典理論での式となる.

最後に伸縮モードに関しては B.V-理論から古典理論 まですべて同じで, $\bar{C}=C_{B}=\sqrt{E / \rho}$ となる.

以上より，自由振動におけるモードパラメーター に対するはりの固有振動数パラメーター 散関係における波数パラメーター $\bar{k}$ に対する波動の固 有振動数パラメーター $\Omega$ の関係とは等価であることを 考慮して,ここでは両者の問題における無次元化固有振 動数スペクトル $\Omega$ と入を単一の図として Fig. 5 に示し, 同様に分散関係の無次元化位相速度スペクトル $\bar{C}$ と別 表示の単純ばりの固有振動数スペクトルえとを単一の 図としてFig.6に示した.なお，いうまでもなくこのよ うな等価性は単純ばりの自由振動の場合のみにみられる

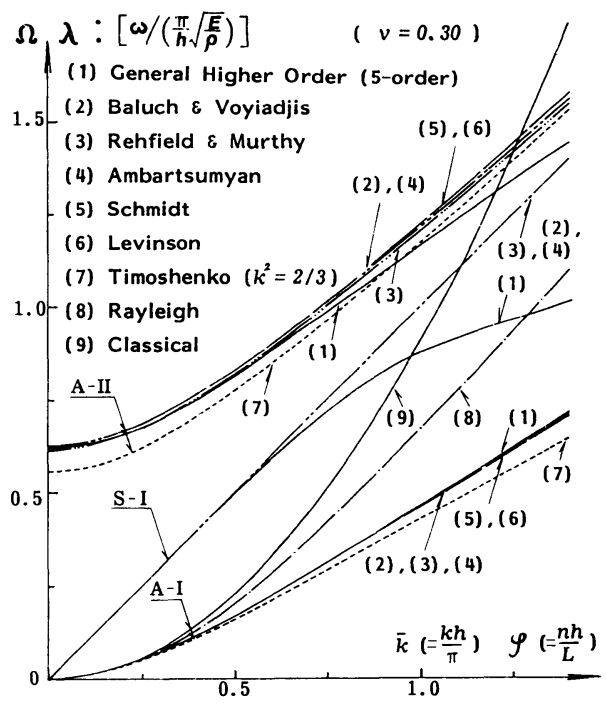

Fig. 5 Phase velocity spectrum $\Omega$ (Eigenfrequency spectrum $\lambda$ ) versus $\bar{k}(\varphi)$ of an isotropic infinite beam (simply supported beam) with $\nu=0.3$. 


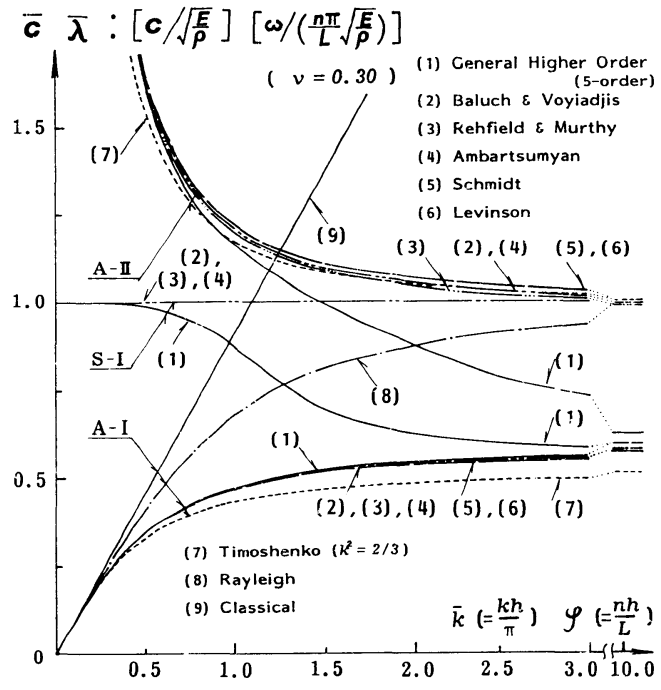

Fig. 6 Phase velocity spectrum $\bar{C}$ (Eigenfrequency spectrum $\bar{\varphi}$ ) versus $\bar{k}(\varphi)$ of an isotropic infinite beam (simply supported beam) with $\nu=0.3$.

著しい特徴であって，他の支持条件のもとではこのよう な等価性は存在しない。

まず，Fig. 5 より次のようなことが読み取れる。逆対 称板厚モードの 1 次のもの (A- I ) においては古典理 論と Rayleigh 理論による值が $\bar{k}$ (あるいは $\varphi$, 以下同 じ）の増大とともに急激に大きな值を示し精度が低下し てゆくが，ここに示したその他の理論における差異は小 さく G. H. - 理論 (5-order) を上限值, T- 理論の值を 下限值として互いに近接した值を示す。なお， $\mathrm{T}$ - 理論 の值は， $x^{2}=2 / 3$ を用いた場合であり， $x^{2}=5 / 6$ と置いた 場合は L-, S-の各理論による值に完全に一致する．逆 対称板厚モ一ドの 2 次のもの (A-II) については, $\bar{k}$ の小さい值の領域では $\mathrm{T}$-理論の值が他とわずかに離れ て小さめの值を示すが, $\bar{k} \fallingdotseq 0.5$ あたりから G. H. - 理論 による值の増加率が徐々に低下しはじめ $\bar{k} \fallingdotseq 1.0$ 以降で は T- 理論の值を下回り最小の值を示しつつ他から離れ てゆく. 一方, その他の理論による值には大差はなく, ほぼ同等の值を示す.

Fig. 6 はこれら各理論における動特性をより大きな波 数パラメーター $\bar{k}$ (あるいは $\varphi$, 以下同じ) について検
討することを目的として分散関係における位相速度パラ メーター $\bar{C}$, ならびに単純ばりの固有振動数パラメー 夕ー $\bar{\lambda} を \bar{k}=0 \sim 3.0,10.0$ について示したものである. この図によって前述の各理論の動特性を別の角度から検 証でき, $\bar{k}$ の大きな值の領域において, (1)古典理論によ る（A- I ）の值が直線的に増加し続け，(2)他の一連の 理論による值は，(S-I）に関してあらゆる領域で一定 值をとり，(3)（A-I），(A-II）での值は， $\bar{k} \fallingdotseq 3.0$ 程度 で各収束值にかなり近い值に達し, その後の変化はごく 小さいのに対し, (4) G. H. - 理論による值は $\bar{k}$ の増大と ともに他の理論に比べ明瞭な変化を示し, 各板厚モード の值が互いに近い値に収束してゆくことがわかる.

\section{6. むす び}

本論文においては, はりにおける変位場を, はりの高 さ方向の座標に関するベキ級数で展開し, 動弾性学にお ける変分原理を用い, はりの高次近似理論式の誘導を 行った。この理論は, 等方性はりはもとより, 一般の異 方性材料よりなる矩形のみならず任意の断面形のはりの 静的, 動的な問題に適用が可能であり，また任意の次数 まで考慮したはり理論の支配式となっている，また，こ の理論で低次の変位係数のいくつかを採用し，構成関係 式を特殊化する，などによって従来提案されている各種 のはり理論が得られることを示した。

また，本論文においては，従来提案されているせん断 変形を考慮した平板曲げの理論をはりに適用した理論を 定式化し, それらの各種のはり理論およびここで求めた 理論によって静的, 動的問題を解析し, それらの計算例 を通じて各種のはり理論の相互関係ならびに精度特性に ついて, 総合的に検討するとともに, ここで導出した理 論の有効性について検討した.

\section{付録 $\mathrm{A}$ 各種のはり理論の支配方程式，変位お よび応力}

ここでは, 各種の動的なはり理論の曲げ挙動に対する 基本式として $w, Q, M$ に関する支配式をマトリックス 形式で表示し, 次に $u_{x}, \sigma_{x}$ および $u_{z}$ の一般形を示す(こ こに $u, w$ は $z=0$ のはりの中心線上の $x$ 方向および $z$ 方向の変位を表わす).

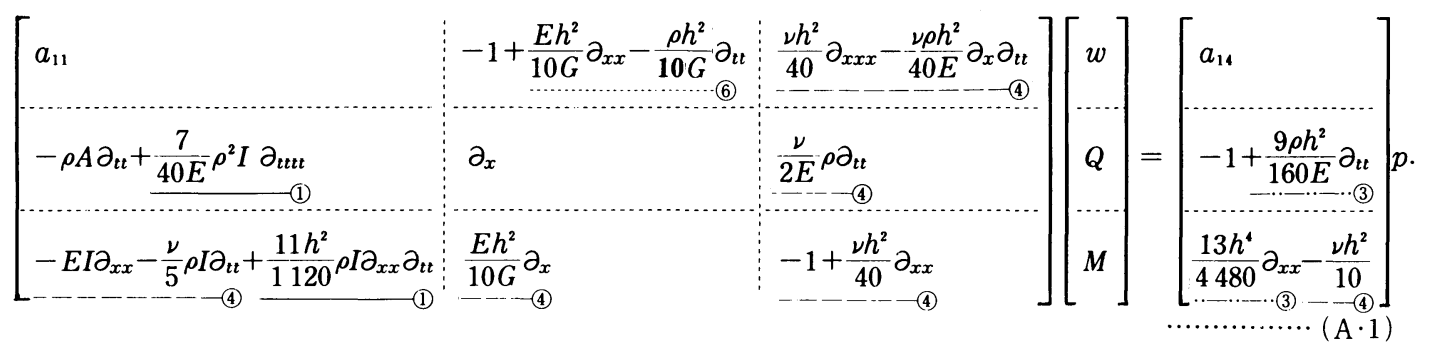




$$
\begin{aligned}
& a_{11}=-E I \partial_{x x x}+\left(1-\frac{\nu}{5}\right) \rho I \partial_{x} \partial_{t t}+\frac{11 h^{2}}{1120} \rho I \partial_{x x x} \partial_{t t}-\frac{11 h^{2}}{1120} \rho^{2} I \partial_{x} \partial_{t t t t}, \quad a_{14}=\frac{13 h^{4}}{4480} \partial_{x x x}-\frac{13 \rho h^{2}}{4480} \partial_{x} \partial_{t t}-\frac{\nu h^{2}}{10} \partial_{x} . \\
& u_{x}=u-z w,_{x}+\frac{z}{2 G A}\left\{3-\left(\frac{2 z}{h}\right)^{2}\right\} Q+\frac{\nu z^{2}}{2 E A} N_{, x}+\frac{\nu z^{3}}{6 E I} M,_{x}+\frac{p, x}{4 E}\left\{z^{2}-\frac{z^{3}}{h}+\frac{2 z^{5}}{5 h^{3}}\right\}+\frac{h}{4 E}\left\{\frac{z^{3}}{3 h}-\frac{2 z^{5}}{5 h^{3}}\right\} \rho \ddot{w},_{x} \\
& \sigma_{x}=E\left\{u, x-z w, x x+\frac{z}{2 G A}\left(3-\left(\frac{2 z}{h}\right)^{2}\right\} Q, x\right\}-\frac{\nu p}{4}\left\{2-3\left(\frac{2 z}{h}\right)+\left(\frac{2 z}{h}\right)^{3}\right\}-\frac{\nu h}{4}\left\{\left(\frac{2 z}{h}\right)-\left(\frac{2 z}{h}\right)^{3}\right\} \rho \ddot{w} \\
& +\frac{\nu z^{2}}{2 A} N,{ }_{x x}+\frac{\nu z^{3}}{6 I} M_{, x x}+\frac{p, x x}{4}\left\{z^{2}-\frac{z^{3}}{h}+\frac{2 z^{5}}{5 h^{3}}\right\}+\frac{h}{4}\left\{\frac{z^{3}}{3 h}-\frac{2 z^{5}}{5 h^{3}}\right\} \rho \ddot{w},_{x x} \\
& u_{z}=w-\frac{p}{4 E}\left\{2 z-\left(\frac{3 z^{2}}{h}\right)+\left(\frac{2 z^{4}}{h^{3}}\right)\right\}-\frac{\nu z^{2}}{2 E I} M-\frac{\nu z}{E A} N-\frac{h}{4 E}\left\{\frac{z^{2}}{h}-\frac{2 z^{4}}{h^{3}}\right\} \rho \ddot{w},{ }_{x}
\end{aligned}
$$

なお，上式において下線部の項を Table A・1 に示した ように削除すれば，それぞれの理論式に帰着する.ただ し, T- 理論は式 $(\mathrm{A} \cdot 4)$ の下線項 (6)の代わりに $z Q / x^{2} G A$ の 1 次関数で置き換えたものとする必要があ る.

Table A.1 Matrix form of governing equation and $u_{x}, \sigma_{x} \mid$ given by eqs. $(\mathrm{A} \cdot 1) \sim(\mathrm{A} \cdot 4)$ due to the various beam theories.

\begin{tabular}{|l|c|c|}
\hline \multicolumn{1}{|c|}{ Theory } & Adopting terms & $K^{2}$ \\
\hline Ref.B.V-theory & all terms & $5 / 6$ \\
B.V-theory & neglect (1) \& (2) & \\
R.M-theory & neglect (1) (3) & $"$ \\
A-theory & neglect (1) (3) & \\
L- \& S-theories & neglect (1) (5) & not \\
T-theory & & fixed \\
Rayleigh theory & neglect (1) (6) & - \\
Classical theory & neglect (1) (7) & - \\
\hline
\end{tabular}

次に, 動的なはり理論の軸方向の伸縮挙動に対する支 配式は次のマトリックス形で与えられる.

$$
\left[\begin{array}{cc}
\rho A \partial_{t t}-\partial_{x}+\frac{\nu \rho I}{2 E A} \partial_{x} \partial_{t t} \\
E A \partial_{x}-1+\frac{\nu h^{2}}{24} \partial_{x x}
\end{array}\right]\left\{\begin{array}{l}
u \\
N
\end{array}\right\}=\left[\begin{array}{c}
\frac{-\frac{\rho I}{4 E} \partial_{x} \partial_{t t}}{\frac{\nu}{2} A-\frac{\nu}{4} \partial_{x x}} \\
-1
\end{array}\right] p
$$

上式は Ref. B. V-理論の支配式であるが，その他の 7 種 の理論は上式の下線項(1)を削除したもので与えられる.

なお，一般化高次理論の支配式その他は本文の第 2 節 で与えられている.

\section{参 考 文 献}

1) Timoshenko, S.P.: On the correction for shear of the differential equation for transverse vibration of prismatic bars, Phil. Mag., Vol.41, pp.744 746, 1921.
2) Timoshenko, S.P. : On the transverse vibrations of bars of uniform cross-section, Phil. Mag. , Vol.43, pp. 125 131, 1922.

3) Rehfield, L. W. and Murthy, P. L. N. : Toward a new engineering theory of bending-Fundamentals, AIAA J., Vol.20, pp. 693 699, 1982.

4）西野文雄・椿 龍哉：せん断変形を考慮したはりの理論, 土木学会第 31 回年次講演会概要集第 I 部, p. 51， 1976.

5) Gupta, A. P. and Pathak, N. : Effect of secondary terms on bending of beams, Indian J. Pure Appl. Math., Vol. 9 , pp. 358 370, 1978.

6) Lo, K. H. , Christensen, R. M. and Wu, E. M. : A high order theory of plate deformation, J. Appl. Mech., Vol. 44, pp. $663 \sim 676,1977$.

7) Voyiadjis, G.Z. and Baluch, M. N. : Refined theory for flexural motion of isotropic elastic plates, J. Sound. Vib., Vol. 76, pp. $57 \sim 64,1981$.

8）平島健一・根岸嘉和：板厚方向の成分を考虑した代表的 な二次元化平板理論の精度に関する考察，土木学会論文 報告集, No. 330, pp. $1 \sim 14,1983$; 数種の平板理論の 動特性（自由振動と分散特性）に関する研究，土木学会 論文報告集, No. 333, pp. 21 34, 1983.

9) Ambartsumyan, S. A. (神谷訳)：異方弾性板の理論, 森北出版, pp. 19 41, 1975.

10) Schmidt, R. : A refined nonlinear theory of plates with transverse shear deformation, J. Indust. Math. Soc., Vol. 27, pp. 23 38, 1977.

11) Levinson, M. : A new rectangular beam theory, J. Sound Vib. , Vol. 74, pp. $81 \sim 87,1981$; Further results of a new beam theory, J. Sound Vib., Vol. 77, pp. 440 444, 1981.

12) Pagano, N. J. : Exact solution for rectangular bidirectional composite and sandwich plates, J. Comp. Mat., Vol. 4, pp. 20 34, 1970.

13) Rayleigh, L. : The Theory of Sound, Dover, 1960.

14) Timoshenko, S. P. and Goodier, J. N. : Theory of Elasticity, McGraw-Hill, pp. 41 50, 1970.

(1983. 10. 15 - 受付) 